\title{
Radoslav Rusňák
}

University of Prešov, Faculty of Education, Prešov, Slovakia radoslav.rusnak@unipo.sk

\section{Slovak Editions of Tales of Long Ago in the Context of New Reading*}

Pregledni rad / review paper

Primljeno / received 14. 12. 2016. Prihvaćeno / accepted 10. 3. 2017.

DOI: 10.21066/carcl.libri.2016-05(02).0005

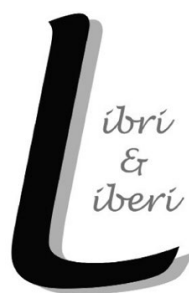

The paper focuses on the concept of world literature for children and young adults, defining its constant, unchanging part and its variable part, which is still in the process of verification. Tales of Long Ago by Ivana BrlićMažuranić is identified as a constituent of world literature for children and young adults. The translation of the collection entered Slovak children's literature thanks to its valuable, as well as pragmatic aspects. The paper evaluates Tales of Long Ago from a genealogical aspect, as a fusion of three genres of children's literature. Two different Slovak editions are addressed: one from 1976, Rozprávky z pradávna [Tales of Long Ago] and the other from 1991, Ctiborova hora a iné rozprávky [Ctibor's Forest and Other Tales], both translations signed by Zlatko Klátik. We are particularly interested in the concept of new reading, which significantly differs for each edition. New reading is defined as a progressive process of the revival of older literary works and reception of foreign literary texts by contemporary children, which brings a new type of pleasure to old tales.

Keywords: Tales of Long Ago, Ivana Brlić-Mažuranić, translation into Slovak, literary translation, new reading, world literature for children and young adults

Based on an artistic understanding of literary works with a dominant aesthetic function, we could wrongly suppose that world literature for children and young adults (YAs), in its four-hundred-year development, had to build on better, more

* The paper is a partial outcome of the grant project VEGA 1/0233/15, Svetová literatúra pre deti a mládež v slovenskom preklade po roku 1990. [World Literature for Children and Young Adults in Slovak Translation after 1990]. 
original and higher quality works. We could think that, in order to become "worldknown", a given work must necessarily be at least one level better in terms of the horizontal-vertical structure than a different work belonging to the same genre. However, this is not true. Without the criteria that world literature generally creates, it is not possible to understand and evaluate the significance of literature; literature is not developing as an art in this sense - therefore, not even in the corpus of world literature for children and young adults is one work considered to be better than another (Durišin 1992: 13; Rakús 1993: 16). Only something which is of the highest value in itself can be considered art. Seen from this perspective, literature is a set of high values.

According to Zlatko Klátik (1973: 650-655), the basic invariant model represents a more general and wider term of world literature, while world literature for children and YAs is built as its variant, defined by its so-called children's aspect (i.e. acceptance of a child's way of perceiving and evaluating reality at a certain level of psychological development). The variability of world literature for children and YAs is, on the one hand, rooted in different ways of its selection and creation; on the other hand, it is defined by the otherness of its determinants, because literature for children and YAs is created and selected by adults, while the child reader ultimately decides whether or not $\mathrm{s} /$ he will accept this offering.

Widely defined, world literature for children and YAs consists of two parts: a constant (unchanging) one and a variable (non-closed) one. Namely, literary artefact does not automatically acquire artistic value; rather, a given society and culture have to assign this value to the artefact. A literary work needs to be accepted as literary reality, which is able to reach specific addressees. Indeed, it does not need to be the society in which the literary work was created, but it might also be a temporally more distant society (or another generation). The constant part of world literature for children and YAs, according to Klátik (1978: 17), also includes classic works of children's literature, and the gaps which are filled in subsequently; the variable part, on the other hand, mirrors the verification process of a given work, the value of which is ultimately defined through time.

As part of world literature for children and YAs, Priče iz davnine, i.e. Tales of Long Ago by the Croatian author Ivana Brlić-Mažuranić, first published in 1916, entered Slovak children's literature in the $20^{\text {th }}$ century in several translations. This is very unusual for the Slovak context of translated literature. Therefore, we might state that, considered from the above-mentioned perspective on world literature for children and YAs, the work of Ivana Brlić-Mažuranić represents its constant, timeverified part. 
There is no doubt that the Croatian author has a stable place among writers of world children's literature. ${ }^{1}$ Although attempts have been made to understand and explain the position of this Croatian author within Slovak children's literature, it remains somewhat unclear. Admittedly, the primary criterion is the axiological aspect, as well as the aspect of a common cultural-historic (Slavic) tradition. The case of Ivana Brlić-Mažuranić could easily be explained through the existence of the so-called non-textual space in a literary text, also known as interference zones (Rakús 1995). This is what might be known as supra-text, i.e. the existence of another (vertical) plane of text, which runs parallel to the linear story plane; the sub-text, i.e. reading between the lines, which does not have a holistic dimension, but always connects with some parts of the literary text; and the post-text, i.e. the space of catharsis, including the ideological message of the story, which is connected to the strong emotional reaction of a reader faced, for instance, with the death of the protagonist. Obviously, these zones always transcend the child in some way, but at the same time enable his/her emotional and spiritual growth in their continual "fulfilment", which could be compared with Lev S. Vygotskij's (1970) zone of proximal development. However, as a secondary criterion we cannot forget the real (pragmatic) aspect, including the contemporary political situation, the experimentation of the author, the cultural politics of the former Czechoslovakia, the subjective tastes of translators, the assertiveness of the author or the inheritors of her copyright, as well as a cluster of completely random circumstances (Klátik 1974).

Our interest in Brlić-Mažuranić's most popular work was not stimulated only by "A Century of Ivana Brlić-Mažuranić's Tales of Long Ago", the international conference held in Zagreb and dedicated to the author. We were also motivated by professional interest in world literature for children and YAs (Rusňák 2009) as well as our participation in the Slovak project ${ }^{2}$ focused on literary scholarship and literary history. So, how can we look at this best-known and most-translated work of Croatian children's literature from the current point of view?

Seen from the current genealogical aspect, the stories in Tales of Long Ago are the result of an interesting fusion of three genres: myth, folktale (folk fairy tale) and literary fairy tale, or "authorial fairy tale" (cf. Rusňák 2012). As a myth, Tales of Long Ago presents a universal Slavic explanation of the world and its functioning,

${ }^{1}$ For instance, Ivana Brlić-Mažuranić is included in the 2007 Czech dictionary of world authors for

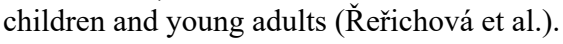

2 World Literature for Children and Young Adults in Slovak Translation after 1960 (2012-2014); World Literature for Children and Young Adults in Slovak Translation after 1990 (2015-2017). 
receptively stimulating concrete models of human behaviour in borderline life situations and simultaneously offering a fundamental way of human perception of the world. As a collection of artistic stories, these tales give the impression that they are a product of collective human creation (which is a typical feature of myths). Moreover, Brlić-Mažuranić's protagonists are not moved by reason, but by emotion, will, desire, faith, and fear. By portraying such protagonists, the stories also present a basic mythical mission: since evil always arises, it is necessary to constantly fight it so the world can be preserved as a place for living. In this fight, man can become weaker and even die, but he can never succumb to evil. Using old-fashioned songs and surreal figurative expressions, the author combined knowledge of Croatian and Slavic mythology and created her own mythical world, in which everything happens in the right and proper way (see Řeřichová et al. 2007).

As a collection of fairy tales, Tales of Long Ago brings together stories organised on the ethical principle: the fight between good and evil. Similar to folktales, BrlićMažuranić also brings together fictional apocryphal stories, unclear and uncertain in terms of time and space. Their endings still have an ethical dimension, as justice always wins. Similar to folktale characters, Brlić-Mažuranić's protagonists are models of ethical categories: they readily stand in clear contrast to one another and reveal more about themselves through their actions than their words. As in traditional folktales, here we can find the magic of numbers, particularly the number three. If we look at Brlić-Mažuranić's stories as folktales in terms of their functions, we could state that they also have the ambition to bring meaning and rules into an irrational (and, for children, chaotic) world, offer meanings and solutions to different life problems, but also a hierarchical reality (cf. Černoušek 1990).

As a collection of authorial fairy tales, Tales of Long Ago represents a metamorphosis of the folktale. On the one hand, the author follows the folktale tradition, but on the other hand she challenges it. In the case of the artistic tale, it is very difficult to define the age suitability of the recipient: age suitability is closely related to the ability to express oneself through a tale addressing elementary ontological issues. From the aspect of the artistic tale, it is obvious that the author does not treat folklore and its simulation arbitrarily: Brlić-Mažuranić shows that even in clearly authorial adaptations, the folklore material is not allowed to crash and irreparably disturb the mythical rule of the world. As artistic creations, the stories in Tales of Long Ago deeply respect the rules of folklore: they do not lose the sense of myth (they preserve the mythical dimension of a forest, nature, fire, sea, etc.); similarly, the Tales of Long Ago does not lose the sense of the deeply rooted familiar dimensions of life (the relationship between man, woman and child, grandfather and grandchildren, siblings, etc.). 
Brlić-Mažuranić's stories could also be labelled as imitations of folktales; in the Slovak context, this kind of artistic tale is characterised as "folklorised". The folklorised artistic tale presents a bond between the folk and the artistic tale; it is like a variant of a folk model. Affirmatively, it remains within the folktale context, without stepping outside its frame in terms of motifs, composition or style. Tales by the Croatian author also incorporate folk motifs, which are transformed through the author's creativity and autonomy. In addition to the folklorised type, they are also close to the symbolic artistic tale (which has a more complex internal structure and rich connotative space, as the vertical storyline hides human issues and develops great ideas within small textual space), as well as the imaginative tale (with a weakened sujet, because of the atmosphere and the sense of the proximity of the reality to magic; in its macrocomposition, the story is a great metaphor).

As we mentioned above, there have been several translations of Tales of Long Ago into Slovak. The collection first appeared in 1931, titled Povesti z pradávna, translated by Anna Dollinayová-Vračanová and with illustrations by Vladimir Kirin. It was published by Vydanie Matice slovenskej in Turčiansky sv. Martin. The translation of the recognised Slovak literary scholar, writer and translator with southern-Slavic roots, Zlatko Klátik, titled Rozprávky z pradávna, appeared with illustrations by Irena Tarasová in Bratislava in 1976, published by Mladé letá. Juraj Tušiak's translation, titled Rozprávky z pradávna, illustrated by István Bálint, was published by Zavod za izdavanje udžbenika in Novi Sad, former Yugoslavia, twice, in 1979 and in 1984. The most recent Slovak edition is that published in 1991 by Mladé letá in Bratislava. It is titled Ctiborova hora a iné rozprávky, and it is another publication of tales in Klátik's translation. However, his text was modified by the language editor Mária Števková, whose adaptations reveal somewhat different strategies.

For the purposes of this paper, which focuses on "new reading" of the literary work of Brlić-Mažuranić, we will consider the last two translations published in Bratislava, those from 1976 and 1991. We have two significant reasons for doing so.

The first comes from the availability of this work by the Croatian author in Slovak libraries. For the purposes of our paper, we contacted the Slovak National Library in Martin, as we needed to find out where in Slovakia Tales of Long Ago was available for Slovak readers. In Slovakia, Tales of Long Ago is available in 27 cities and 31 public libraries in total. However, only the last two publications of 1976 and 1991 are available. As mentioned above, in both cases Zlatko Klátik is named as the translator, but the texts differ due to the language editing of the latter edition. Copies of the translation into Slovak published in the first half of the $20^{\text {th }}$ century are practically inaccessible to "ordinary" readers (in many cases, they 


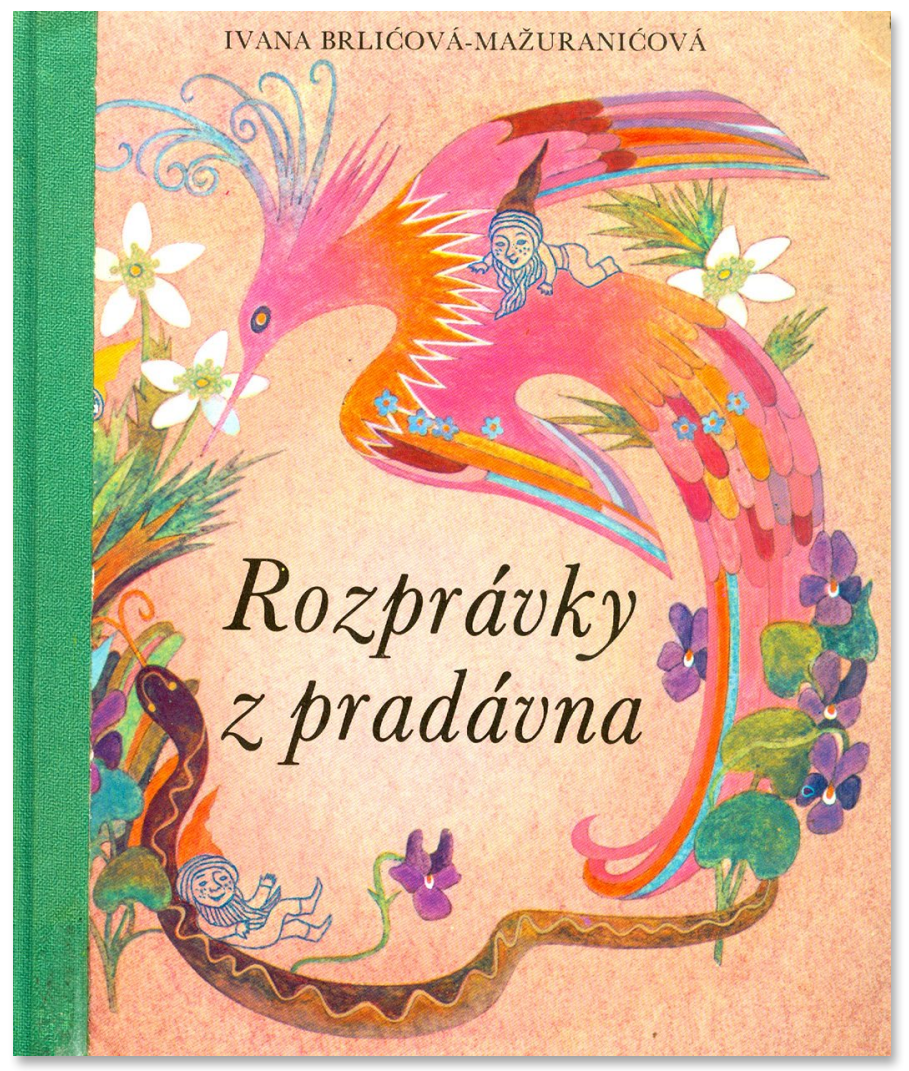

Fig. 1. The front cover of the Slovak edition of Tales of Long Ago of 1976.

Sl. 1. Prednja strana korica slovačkoga izdanja Priča iz davnine iz 1976.

are placed in the archives or removed from the catalogues and from the shelves, possibly due to the disinterest of readers). ${ }^{3}$

The second reason is our interest in the concept of new reading of this Croatian author's works: for this purpose, the last two Slovak publications of the book (with the same translator, but a different concept) are the most suitable. In fact, both publications appeared in diametrically different societal, cultural, and also political circumstances, which significantly influenced the readers' perception and the appeal of the work for Slovak children.

The 1976 edition of Tales of Long Ago (Fig. 1) has been found in the third biggest Slovak city, Prešov.

3 Tušiak's translation is not available to Slovak readers in Slovakia, as his translation probably never reached Slovak libraries, and Dollinayová-Vračanová's translation is only in the holdings of the Slovak National Library; it is removed from both shelves and catalogues of Slovak public libraries (probably sold cheaply in a book market of ,unwanted“ books). It would be most unfortunate if this happens to be the destiny of Klátik's translation from 1976, too. 


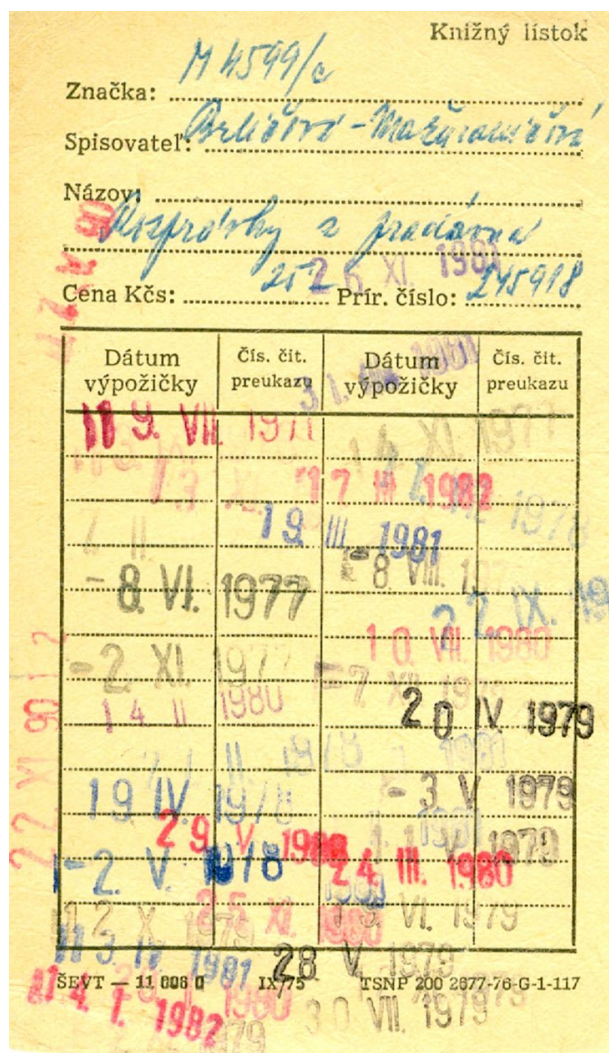

Fig. 2. A lending record card, front.

Sl. 2. Prednja strana knjižnoga listića.

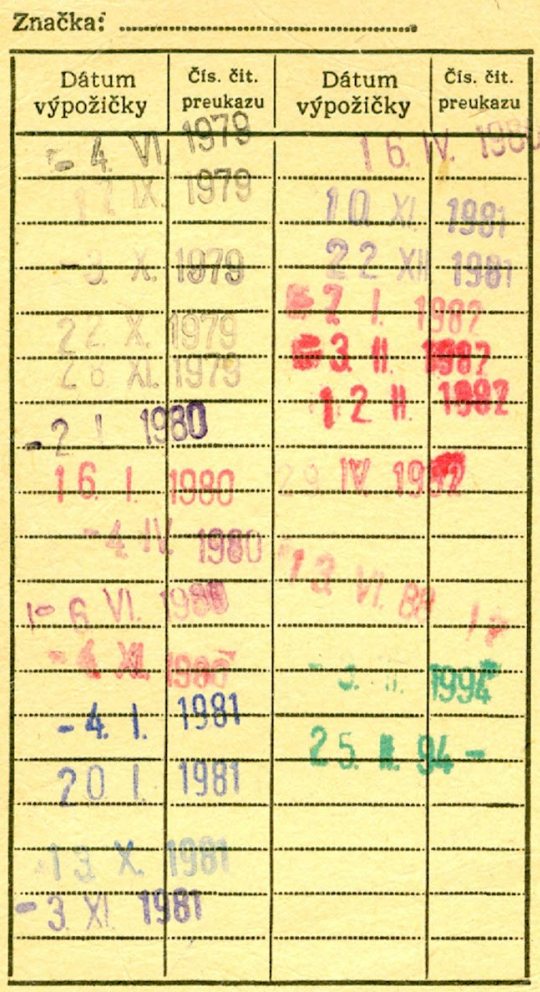

Fig. 3. A lending record card, back.

Sl. 3. Stražnja strana knjižnoga listića.

However, the book was not available in the central children's library, only in its branch office in one of Prešov's suburbs (which was quite surprising for us). Some of the books were long in the possession of this library, and in the copy used in this research, the library lending record card has not been removed, which helped us explore the reading fate of the collection in the hands of Slovak children through time (Figs. 2, 3). The book had been borrowed quite regularly in the period 1977-1982, then a couple of times in the mid 1980s, and its only borrowing after that was in 1994.

The most important milestone in the history of the Slovak translation of Tales of Long Ago is 17 November 1989. In that year, the Velvet Revolution took place in the former Czechoslovakia, which completely changed the political and socio-cultural situation in the common state of Czechs and Slovaks (which in 1993 was definitively separated into two independent states, the Czech Republic and the Slovak Republic). Since November 1989, as Zuzana Stanislavová (2010) 


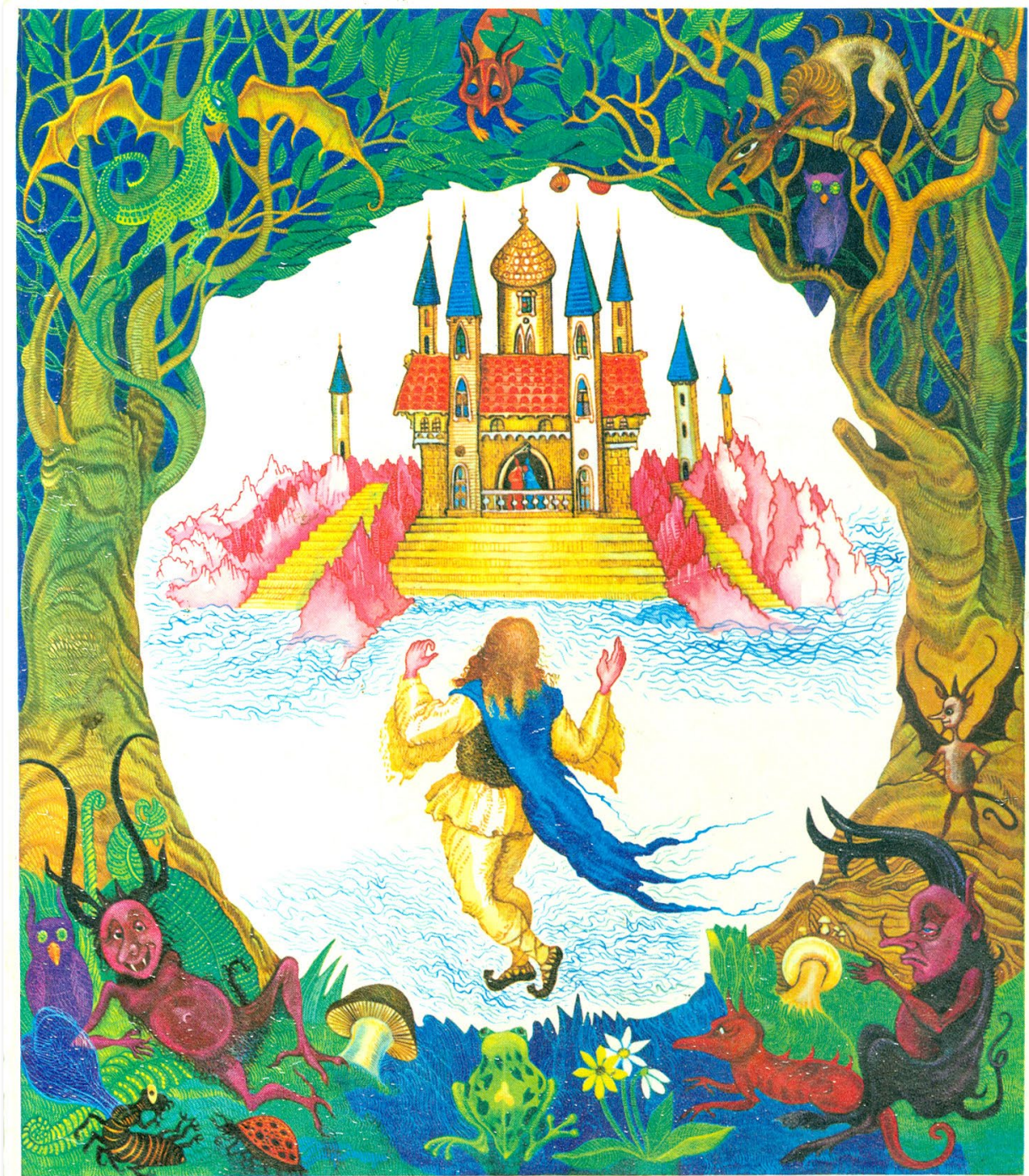

Ivana Brlićová-Mažuranićová

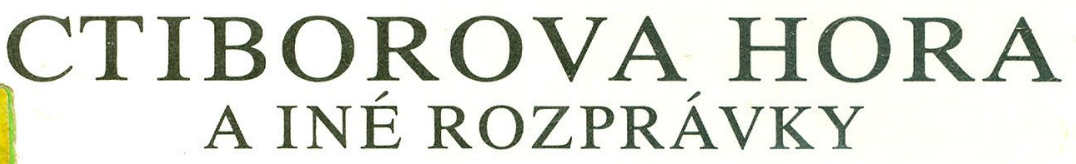

Fig. 4. The front cover of the Slovak edition of Tales of 1991.

Sl. 4. Prednja strana korica slovačkoga izdanja Priča iz 1991. 
mentions, significant changes occurred on the Slovak book market, as well as in the field of publishing, in the span of several years. Some of the changes also relate to market mechanisms, which were established in the field of culture as well, and thus children's books became a source of profit. This meant that Slovak publishing houses started to focus on publishing commercial and trivial titles, mainly foreign ones. In Slovakia, a value and reading crisis occurred very quickly, and this completely changed both publishing and reading habits. This fact is recorded in the library lending record card - especially with the last three dates between 1989 and 1994: one from 1990 and two from 1994, obviously extended borrowing by the same person.

More interesting is the fact that Brlić-Mažuranić's book was published again in 1991 (i.e. two years after the political and social changes in Czechoslovakia), once again in Klátik's, albeit edited, translation. This edition is a selection of stories from the original collection of Tales of Long Ago, published under the title Ctibor's Forest and Other Tales and with illustrations by the Croatian artist Cvijeta Job (Fig. 4).

If we compare these two publications of the book, we come to some interesting findings that can best describe the concept of new reading. By "new reading" we do not mean the second reading of the same text, which, according to P. Nodelman and M. Reimer (2003: 45), changes the reader's pleasure, because s/he knows what is going to happen. Rather, what we have in mind is the interpretative variation and modification of original literary works, which is supposed to contribute to their repeated attractiveness within world literature for children and YAs. If we return to the introductory explanation of what the meaning of world literature for children and YAs is, we have to state that Ivana Brlić-Mažuranić's book undoubtedly belongs to the constant part of world children's literature. Even so, the book has almost disappeared from the real reading of Slovak children. The concept of new reading of Rozprávky z pradávna (1976), as well as the selection of tales titled Ctibor's Forest and Other Tales (1991), which has the potential to bring Ivana Brlić-Mažuranić back to the reading of Slovak children, is briefly summarised in Table 1, by means of a comparison of two editions.

As seen, the more recent 1991 publication is interesting from the perspective of new reading as it contains only a selection of tales from the original collection (four of the original eight tales; and reasons for selecting those four tales are not clear or even explained). One of those - "Ctibor's Forest" - lent its title to the entire collection. However, we can see that the title was actualised and modified: "Stribor's Forest" was modified to "Ctibor's Forest". Stribor is a name taken from Slavic mythology: its current and, for children, more understandable form in the Slovak language is Ctibor. This name communicates a meaning to Slovak readers: one who fights for honour. 
Table 1. A comparison of two Slovak editions of Tales of Long Ago.

Tablica 1. Usporedba dvaju slovačkih izdanja Priča iz davnine.

\begin{tabular}{|l|l|l|}
\hline Year of publication & $\mathbf{1 9 7 6}$ & $\mathbf{1 9 9 1}$ \\
\hline Title (in English translation) & Croatian Tales of Long Ago & Ctibor's Forest and Other Tales \\
\hline Number of pages & $178 \mathrm{pp}$. & $94 \mathrm{pp}$. \\
\hline Format & A5 & A4 \\
\hline Typography & Smaller font size & Larger font size \\
\hline Illustrator & Irena Tarasová (Slovak) & Cvijeta Job (Croatian) \\
\hline Illustrations vs. text & $\begin{array}{l}\text { A few illustrations over a number } \\
\text { of pages }\end{array}$ & $\begin{array}{l}\text { Numerous illustrations over a } \\
\text { number of pages }\end{array}$ \\
\hline Included tales & $\begin{array}{l}\text { Stribor's Forest } \\
\text { Fisherman Plunk and his Wife } \\
\text { How Quest Sought the Truth } \\
\text { Toporko the Wanderer and the } \\
\text { Nine Princes } \\
\text { Reygoch } \\
\text { Little Brother Primrose and } \\
\text { Sister Lavender } \\
\text { Bridesman Sun and Bride } \\
\text { Bridekins }\end{array}$ & $\begin{array}{l}\text { Fisherman Plunk and his Wife } \\
\text { How Quest Sought the Truth } \\
\text { Topor the Wanderer and the } \\
\text { Nine Princes }\end{array}$ \\
\hline Editorial tendency & Mythological concept emphasised & $\begin{array}{l}\text { Tale-fantastic concept } \\
\text { emphasised }\end{array}$ \\
\hline Epilogue (about the author) & Yes (pp. 171-174) & Absent \\
\hline Explanatory notes & Yes (pp. 175-178) & Absent \\
\hline Intention & Two implied readers & One implied reader \\
\hline
\end{tabular}

In this part of the paper, we take a closer look at the literary aspects of the tale "Stribor's Forest" published in 1976, with reference to its 1991 publication as "Ctibor's Forest".

From the point of view of composition, in the fairy tale "Ctibor's Forest" the literary-artistic artefact is created by various principles, which influence its internal composition. Several principles can be found in one text in different forms. In "Ctibor's Forest" we can identify the following compositional principles (see Všetička 2001): the contrast principle, the route principle, the hooding principle (the disguising of the character), and the motivic principle (the motif of a snake, fire, elf/brownie, and forest). 
The contrast principle within the text tectonic belongs to one of the oldest and most frequently implemented principles. Its basic characteristic, which defines it and on which it is built, is the principle of opposition, contrast. In the form of contrast, this principle not only allows the expression of human relationships and attitudes, but gives them a tone of urgency and clarity as well. The fairy tale contrasts the femininity element, represented by two female protagonists: the mother - the main protagonist around whom the story revolves (however, it is an unusual main character for a fairy tale laden with folklore) and the bride - in the role of pest, antagonist (typical of folktales) and the shrew. At the same time, the viper-bride is a disturbing character. Indeed, at the beginning of the story she suddenly steps into a foreign and already stable environment, and disturbs the calm family relationship between the mother and son, deflects him and disappears again at the end of the story. This character's behaviour is such that all the protagonists have to take a stand - either positive (son), or negative (mother, brownies, Ctibor). Essentially, the character of the viper-bride is different from the others - she possesses certain magical powers.

The route principle is a typical compositional principle in folktales, implemented in the story of Ctibor's forest as well. On the journey to Ctibor, the main character, the mother, travels to seek redemption for her son, enchanted by the viper-bride. During the journey to her destination, she is pursued by the adversary (bride); however, this tracking will not have any impact on the plot. After meeting Ctibor, the forest ruler, the mother rejects the offered solution to her problem, because it would require her to forget her son - to give up the role of mother. The main protagonist rejects Ctibor's tempting offer to return to the period of her youth, because she considers motherhood to be the most precious thing in her life, despite her son being unworthy.

The hooding principle is based on a character wearing a disguise. Characters pretend to be someone they are not and beguile others against their will. In the analysed story, this principle is explicitly implemented through the role of the bride, who is essentially a dark soul, cursed into a serpentine form. The beauty of the girl is only her mask, needed in order for her to selfishly survive (only the one who would marry her could survive her). Implicitly, the hooding principle occurs in the shy and timid son, who is influenced by the viper-woman to such an extent that he develops hatred for his good mother (the nature of the snake is such that she can hypnotise her victim).

The motivic principle is always the most important principle in the construction of a literary work. As the name of the principle suggests, its basic element is a motif. In the story of "Ctibor's Forest", the following dominant motifs can be identified: 
the snake, fire, brownie, and forest (see Richter 2004). In our opinion, these motifs contribute the most to the artistic persuasiveness of Brlić-Mažuranić's story/stories and thus lend her work an axiological timelessness. Motivic construction and its encryption of meaning also contribute to the reading experience (so important for literature), on which the very existence of literature as a literary artistic artefact is built.

In the world of folktales, the snake motif embodies danger, smoothness, cunning, a mysterious gripping quality (the ability to hypnotise the victim) as well as the fear of poison. Through its attachment to the ground, the snake motif is more engaged with underground evil forces and, from a Biblical perspective, it is seen as an ally of the devil, even as a self-reincarnation of the devil. The feminine nature and essence are usually attributed to the snake, which is a symbol of sexual lust and, because of its poison, death and destruction (interchangeable with the dragon in fairy tales). The viper-woman in Brlić-Mažuranić's story is originally a sinful soul, and therefore founds her transitional physical shape in a snake. After her transformation into a woman, her only weaknesses are the snake's forked tongue and snake instincts, which ultimately turn against her.

In folktales, the fire or fireplace motif is a symbol of life, its cycle, but also of purification and transformation. Moreover, fire in the house is a symbol of home and has a link to basic needs: warmth, food, and safety. From a mythological perspective, fire has a link to the cult of ancestors: the fireplace is where dead ancestors remain. As a flame, fire is a reflection of spirituality and spiritual power. In our story, fire signifies home and maternal care, but also appears as a source of spiritual and magical forces (the good): the brownies, and especially Pinkie Tintilíček who acts as the main helper and supporter of the old mother.

In Slavic folklore, elves/brownies are little domestic ghosts, fairy figures, who come to the fireplace and mostly do a lot of damage. In the Slovak context, these kinds of elves were commonly known as zmok or rarášok. As a brownie (an elf which belongs to Croatian folklore), Pinkie Tintilíček fulfils the important role of helper of the main protagonist.

The forest motif has a significant mythological dimension for Slavic nations. It is seen as a dark place associated with wandering, a place of getting lost or being abandoned, a place of disorientation, danger, threat, and tests. At the same time, it is an unknown and mysterious place. Simultaneously, the forest motif represents a place where the fate of a man is decided, where routes are lost, changed, or derived. As such, the forest in the analysed story is the residence of the forest ruler Ctibor. According to Slavic mythology, Stribor was the god of the winds, but the author has creatively changed his mythological role and turned him into a fairy creature, full 
of magical powers. As the mother's guide on her journey to Ctibor, a deer appears, a symbol of dignity and majesty, but also a messenger or a guardian. In the mythology of primeval nations, the deer is a symbol of light; this connotation is also found in our story, where the deer has a little star on each horn and thus lights the road during the night-time journey. Surprisingly, the deer is also seen as opposite to the snake. Moreover, the deer is associated with speed, fertility, freshness, and restoration.

If we compare the story of "Stribor's Forest" and "Ctibor's Forest" in the two analysed editions of Brlić-Mažuranić's stories in Slovak (1976 and 1991), we can find that "Ctibor's Forest" (1991) contains more than 160 different modifications at various levels (from small ones to more significant changes) when compared to Klátik's original translation of the story (1976). However, seen as a whole, all of these lexical-stylistic corrections give the story of "Ctibor's Forest" (as well as the other three tales published in this selection) the character of new reading (Table 2).

Table 2. A comparison of two Slovak editions of Tales of Long Ago: differences in the texts of the translation. Selected examples.

Tablica 2. Usporedba tekstova dvaju slovačkih izdanja Priča iz davnine. Izabrani primjeri.

\begin{tabular}{|c|c|c|}
\hline Publication year & 1976 & 1991 \\
\hline Comparison: & \multicolumn{2}{|c|}{ (The examples are translated literally into English.) } \\
\hline \multirow[t]{3}{*}{$\begin{array}{l}\text { At the level of } \\
\text { word order }\end{array}$} & $\begin{array}{l}\text { zostalo } \mathrm{v} \text { ústach } \\
- \text { remained in the mouth }\end{array}$ & $\begin{array}{l}\mathrm{v} \text { ústach zostalo } \\
- \text { in the mouth remained }\end{array}$ \\
\hline & $\begin{array}{l}\text { stará slepaňa } \\
\text { - the old blind one }\end{array}$ & $\begin{array}{l}\text { slepaňa stará } \\
\text { - the blind old one }\end{array}$ \\
\hline & $\begin{array}{l}\text { zočila znezrady } \\
\text { - faced suddenly }\end{array}$ & $\begin{array}{l}\text { znezrady zočila } \\
\text { - suddenly faced }\end{array}$ \\
\hline \multirow{2}{*}{$\begin{array}{l}\text { At the level of } \\
\text { proper names }\end{array}$} & Stribor & Ctibor \\
\hline & $\begin{array}{l}\text { Malíček Tintilínček } \\
\text { - Pinkie Tintilinček }\end{array}$ & $\begin{array}{l}\text { Malíček Tintilííek } \\
\text { - Pinkie Tintiličck }\end{array}$ \\
\hline \multirow{5}{*}{$\begin{array}{l}\text { At the level of } \\
\text { general names/ } \\
\text { words }\end{array}$} & $\begin{array}{l}\text { klát } \\
-\log \end{array}$ & $\begin{array}{l}\text { peň } \\
\text { - tree stump }\end{array}$ \\
\hline & $\begin{array}{l}\text { premieňala } \\
\text { - converted }\end{array}$ & $\begin{array}{l}\text { premenila } \\
\text { - changed }\end{array}$ \\
\hline & $\begin{array}{l}\text { vystupujú z plameňa } \\
\text { - act from the heat }\end{array}$ & $\begin{array}{l}\text { vyskakujú z plameňa } \\
\text { - jump out of the heat }\end{array}$ \\
\hline & $\begin{array}{l}\text { tancujú po ohnisku } \\
\text { - dancing by the fireplace }\end{array}$ & $\begin{array}{l}\text { roztancujú sa po ohnisku } \\
\text { - dancing on the fireplace }\end{array}$ \\
\hline & $\begin{array}{l}\text { rozkázala } \\
\text { - commanded }\end{array}$ & $\begin{array}{l}\text { zapovedala } \\
\text { - ordered }\end{array}$ \\
\hline
\end{tabular}




\begin{tabular}{|c|c|c|}
\hline Publication year & 1976 & 1991 \\
\hline \multirow[t]{11}{*}{$\begin{array}{l}\text { At the level of } \\
\text { collocations }\end{array}$} & $\begin{array}{l}\text { odpočinút' v pekný zimný deň } \\
\text { - relax on a nice winter day }\end{array}$ & $\begin{array}{l}\text { odpočinút', pretože bol pekný zimný } \\
\text { den̆ } \\
\text { - relax, because it was a nice winter } \\
\text { day }\end{array}$ \\
\hline & $\begin{array}{l}\text { syn sa na to zasmial } \\
- \text { son laughed at it }\end{array}$ & $\begin{array}{l}\text { syn sa na tie reči zasmial } \\
- \text { son laughed at those words }\end{array}$ \\
\hline & $\begin{array}{l}\text { smelý a bystrý mládenec by na ňu } \\
\text { hned' zamával sekerou a skríkol... } \\
\text { - a courageous and bright young } \\
\text { man would soon wave at her with } \\
\text { an axe and shout }\end{array}$ & $\begin{array}{l}\text { keby teraz pred ňou smelý a bystrý } \\
\text { mládenec zamával sekerou } \\
\text { a skríkol... } \\
\text { - if now in front of her a courageous } \\
\text { and bright young man waved an } \\
\text { axe and shouted }\end{array}$ \\
\hline & $\begin{array}{l}\text { mamička } \\
- \text { mommy }\end{array}$ & $\begin{array}{l}\text { mamička moja } \\
- \text { my mom }\end{array}$ \\
\hline & $\begin{array}{l}\text { stálo tam vysoké bralo } \\
\text { - there stood a high cliff }\end{array}$ & $\begin{array}{l}\text { obd'aleč stálo vysoké bralo } \\
\text { - nearby stood a high cliff }\end{array}$ \\
\hline & $\begin{array}{l}\text { a jedného dňa rozkáže } \\
\text { - and one day he will command }\end{array}$ & $\begin{array}{l}\text { a tu jedného dňa rozkáže } \\
\text { - and here one day he will command }\end{array}$ \\
\hline & $\begin{array}{l}\text { prizrie sa dievčine } \\
\text { - looks at the girl }\end{array}$ & $\begin{array}{l}\text { prizrie sa peknej dievčine } \\
\text { - looks at the nice girl }\end{array}$ \\
\hline & $\begin{array}{l}\text { zapláta synovu košel'u } \\
\text { - mends the son's shirt }\end{array}$ & $\begin{array}{l}\text { zapláta synovu roztrhanú košel'u } \\
\text { - mends the son's torn shirt }\end{array}$ \\
\hline & $\begin{array}{l}\text { starenka bola ako omladnutá } \\
\text { - the old woman was like } \\
\text { juvenescence }\end{array}$ & $\begin{array}{l}\text { starenka akoby omladla } \\
\text { - the the old woman appeared to } \\
\quad \text { rejuvenate }\end{array}$ \\
\hline & $\begin{array}{l}\text { že sa kolo } \mathrm{v} \text { tanci zastavilo } \\
\text { - that the wheel stopped dancing }\end{array}$ & $\begin{array}{l}\text { že sa tanec hned' zastavil } \\
\text { - that dancing stopped immediately }\end{array}$ \\
\hline & $\begin{array}{l}\text { pomôžte mi prizriet' sa na jazyk } \\
\text { mojej nevesty } \\
\text { - help me to have a look at my } \\
\text { bride's tongue }\end{array}$ & $\begin{array}{l}\text { či by ste mi vedeli pomôct' prizriet' sa } \\
\text { na jazyk mojej neveste } \\
\text { - could you help me to have a look } \\
\text { at my bride's tongue }\end{array}$ \\
\hline $\begin{array}{l}\text { At the level } \\
\text { of sentence } \\
\text { structure }\end{array}$ & $\begin{array}{l}\text { Večer vraví nevesta starenke: } \\
\text { „Pôjdem na návštevu ku kmotre, } \\
\text { a ty, kým sa vrátim, prihrej vodu!“ } \\
\text { - In the evening, the bride tells the } \\
\text { old lady: "I am going to visit the } \\
\text { godmother, and until I come, you } \\
\text { warm up the water!” }\end{array}$ & $\begin{array}{l}\text { Ubehol deň a večer vraví nevesta } \\
\text { starenke: ,Zájdeme s mužom ku } \\
\text { kmotre na návštevu, a ty prihrej } \\
\text { vodu, kým sa vrátime!“" } \\
\text { - A day passed away and in the } \\
\text { evening the bride tells the old } \\
\text { woman: "With my husband, we are } \\
\text { going to visit the godmother, and } \\
\text { you warm up the water until we } \\
\text { come back!" }\end{array}$ \\
\hline
\end{tabular}




\begin{tabular}{|c|c|c|}
\hline & $\begin{array}{l}\text { Ked's mužom odišla preč, starenka } \\
\text { osamela, vzala triesky od } \\
\text { dievčiny, nakládla oheň v ohnisku } \\
\text { a šla do kôlne po drevo. } \\
\text { - When she left with her man, the } \\
\text { old woman stood alone, took the } \\
\text { girl's kindling-wood, lit the fire } \\
\text { in the fireplace, and went to the } \\
\text { shed for wood. }\end{array}$ & $\begin{array}{l}\text { Starenka osamela, vzala triesky, ktoré } \\
\text { jej dala dievčina, nakládla oheň } \\
\text { v ohnisku a šla do kôlne po drevo. } \\
\text { - The old woman stood alone, took } \\
\text { the kindling-wood that the girl } \\
\text { had given her, lit the fire in the } \\
\text { fireplace, and went to the shed for } \\
\text { wood. }\end{array}$ \\
\hline & $\begin{array}{l}\text { Starenke sa to v noci videlo čudné } \\
\text { a vrátila sa do kuchyne. } \\
\text { - The old woman found it strange } \\
\text { at night, and she went back to the } \\
\text { kitchen }\end{array}$ & $\begin{array}{l}\text { Starenke sa to zdalo čudné, čo sa deje } \\
\text { v noci, a vrátila sa do kuchyne. } \\
\text { - The old woman found it strange } \\
\text { what it was happening at night, } \\
\text { and she went back to the kitchen. }\end{array}$ \\
\hline & $\begin{array}{l}\text { Starenka všetko piadimužíkom } \\
\text { vyrozprávala. } \\
\text { - The old woman told the brownies } \\
\text { everything. }\end{array}$ & $\begin{array}{l}\text { Starenka vyrozprávala piadimužíkom } \\
\text { všetko tak, ako bolo. } \\
\text { - The old woman told the brownies } \\
\text { everything just as it was. }\end{array}$ \\
\hline $\begin{array}{l}\text { At the level of } \\
\text { a compound } \\
\text { sentence }\end{array}$ & $\begin{array}{l}\text { Starenka bola ako omladnutá, } \\
\text { zasmiala sa ako hrdlička. } \\
\text { Vyskočila ako dievčatko } \\
\text { a vychytila sa s piadimužíkmi } \\
\text { tancovat'. } \\
\text { - The old woman was like } \\
\text { juvenescence, laughed like a } \\
\text { turtle-dove. She jumped like a } \\
\text { little girl and wanted to dance } \\
\text { with the brownies. }\end{array}$ & $\begin{array}{l}\text { Starenka akoby omladla - zasmiala } \\
\text { sa ako hrdlička, vyskočila } \\
\text { ako dievčatko a vychytila sa } \\
\text { s piadimužíkmi tancovat. } \\
\text { - The old woman rejuvenated } \\
\text { suddenly - she laughed like a dove, } \\
\text { jumped like a little girl and wanted } \\
\text { to dance with the brownies. }\end{array}$ \\
\hline $\begin{array}{l}\text { At the level of } \\
\text { addition }\end{array}$ & --- & $\begin{array}{l}\text { Prosil syn boha i matku, aby mu } \\
\text { odpustila. } \\
\text { - The son begged God and mother to } \\
\text { forgive him. }\end{array}$ \\
\hline
\end{tabular}

In the context of new reading, we can state that such a large amount of changes and various modifications in the text of one translation did not occur solely because of the lexical update and stylistic modification of the text after fifteen years. The modification of the original translation of Brlić-Mažuranić's tales of 1976 includes (not only in the analysed "Ctibor's Forest", but in other tales as well) more ceremony and folktale conventions. Parentheses (inserts), inversions, flowery adjectives and full sentences, shortening of long compound sentences, lexicalstylistic interventions, etc., are all eloquent editing interventions, supported also by the choice of the surrealist illustrations by Cvijeta Job. In their aesthetic effect, they are particularly close to the similarly surrealist world of the painter and illustrator of Slovak folktales and legends, Albín Brunovský.

As shown in Table 1, Brlić-Mažuranić's collection published in Slovak translation in 1976 in A5 format had more pages (178 pp); the compilation from 1991 was published in A4 format and was slenderer (94 pp). The difference is 
obvious also in font typography, which is different in these publications, and in the amount of illustrations per total number of pages. The publication from 1976 has smaller font size and only a few illustrations by the Slovak illustrator Irena Tarasová; the 1991 publication has larger font size and rich ("child friendly") illustrations by Cvijeta Job. Both publications also differ in their editorial tendency; it is obvious that the 1976 publication has a more prominent mythological Slavic dimension of the literary text, which corresponds to the inclusion of the Croatian author's epilogue with explanatory notes related to the names of the characters in the tales derived from the Slavic mythological context. However, the 1991 publication does not contain this, because its intention is to intensify and strengthen its tale-fantastic character (generally, child readers read myths like tales, i.e. without perceiving their mythological core and archetypal dimension).

We can state that another difference between the publications lies in the category of implied reader. According to Nodelman and Reimer (2003: 17), it is not only the quality that makes a specific kind of reader the implied reader - it is the role which the text indicates and invites the real reader to fulfil. A reader has to identify with an implied reader in a certain way and at a certain level. However, Klátik's translation from 1976 actually had two implied readers: a pseudo-addressee and a real addressee. Indeed, the child in this translation is more of an excuse while the adult reader is the real addressee (cf. Nodelman \& Reimer 2003: 55). On the other hand, the 1991 compilation has only one implied reader: the child, becoming both the primary intended reader and the real addressee at the same time.

The aim of this paper is not to evaluate changes in the editions of the text in terms of their adequacy. The changes are perceived rather as indicators of a new reading of old tales.

The paradox of the great works of world literature for children and YAs lies in the fact that they are acknowledged for their uniqueness, as well as for the versatility of their content. Tales of Long Ago by Ivana Brlić-Mažuranić is important for both its uniqueness and versatility. It would be sad if this artistically convincing work - which teaches readers not to forget their past in order not to lose their future disappeared from what children actually read. In order to avoid this, new readings of old texts could renew or restart the original life of the work, even at the cost of various modifications and variations in translation, interpretation and reception of text. Moreover, as H.G. Gadamer states, the meaning of a text is never depleted by the intentions of its author (as quoted in Compagnon 2006: 66). When a text moves from one historical or cultural context to another, new meanings are assigned, which neither the author nor the original reader predicted. Therefore, each interpretation is contextual and depends on the criteria of the context in which it takes place. The concept of new reading of Ivana Brlić-Mažuranić in Slovak translation is a 
contextual reading, particularly in relation to the new situation of contemporary children and their reading habits.

\section{References}

Brlić-Mažuranićová, Ivana. 1976. Rozprávky z pradávna [Tales of Long Ago]. Bratislava: Mladé letá.

Brlić-Mažuranićová, Ivana. 1991. Ctiborova hora a iné rozprávky [Ctibor's Forest and Other Tales]. Bratislava: Mladé letá.

Compagnon, Antoine. 2006. Démon teórie. Literatúra a bežné myslenie. Bratislava: Kalligram.

Černoušek, Michal. 1990. Děti a svět pohádek. Praha: Albatros.

Ďurišin, Dionýz. 1992. Čo je svetová literatúra? Bratislava: Obzor.

Klátik, Zlatko. 1973. “O pojme a výskume svetovej literatúry pre deti a mládež 1". Zlatý máj 12 (10): 650-655.

Klátik, Zlatko. 1974. “O pojme a výskume svetovej literatúry pre deti a mládež 2”. Zlatý máj 13 (1): 15-20.

Klátik, Zlatko. 1978. Svetová literatúra pre mládež (profily a prehl'ady). Bratislava: SPN.

Nodelman, Perry \& Mavis Reimer. 2003. The Pleasures of Children's Literature. $3^{\text {rd }}$ ed. Boston: Allyn \& Bacon.

Rakús, Stanislav. 1993. Medzi mnohoznačnostou a presnostou. Levoča: Modrý Peter.

Rakús, Stanislav. 1995. Poetika prozaického textu. Bratislava: Slovenský spisovatel'.

Richter, Luděk. 2004. Co je co v pohádce. Praha: Dobré divadlo dětem.

Řeřichová, Vlasta et al., eds. 2007. Autoři světové literatury pro děti a mládež. Multimedia CD-ROM. Olomouc: nakladatelství Olomouc.

Rusňák, Radoslav. 2009. Svetová literatúra pre deti a mládež v didaktickej komunikácii. Prešov: Prešovská univerzita v Prešove, Pedagogická fakulta.

Rusňák, Radoslav. 2012. "Variants of Authorial Fairy Tale and the Current Children Audience". Practice and Theory in Systems of Education 7 (2): 153-158.

Stanislavová, Zuzana et al., eds. 2010. Dejiny slovenskej literatúry pre deti a mládež po roku 1960. Bratislava: Literárne informačné centrum.

Všetička, František. 2001. Tektonika textu. Olomouc: Votobia.

Vygotskij, Lev Semionovič. 1970. Myšleni a řeč. Praha: SPN.

\section{Radoslav Rusňák}

Obrazovni fakultet, Sveučilište u Prešovu, Prešov, Slovačka

Pädagogische Fakultät der Universität Prešov, Prešov, Slowakei

\section{Priče iz davnine na slovačkome u kontekstu novoga čitanja}

Rad se bavi konceptom svjetske književnosti za djecu i mladež koja se dijeli na stalni, nepromjenjivi dio i na promjenjivi dio koji je još u fazi prepoznavanja i priznavanja. Priče iz davnine Ivane Brlić-Mažuranić ubrajaju se u njezin stalni dio. Prijevod te zbirke ulazi 
u slovačku dječju književnost zahvaljujući svojemu vrijednosnomu, ali i pragmatičnomu aspektu. U radu se Priče iz davnine razmatraju sa žanrovskoga stajališta, kao spoj triju žanrova dječje književnosti. Analiziraju se dva različita slovačka izdanja: Rozprávky $z$ pradávna (Priče iz davnine) iz 1976. i Ctiborova hora a iné rozprávky (Ctiborova šuma i druge priče) iz 1991. godine, koje kao prevoditelj potpisuje Zlatko Klátik, pri čemu je tekst drugoga izdanja jezično izmijenjen. Posebna se pozornost posvećuje konceptu novoga čitanja, koji se oslanja na razlike u tekstovima. Novo čitanje definira se kao progresivni proces revitalizacije starijih izdanja i suvremene dječje recepcije stranih književnih tekstova, a omogućuje novu vrstu uživanja u starim pričama.

Ključne riječi: Priče iz davnine, Ivana Brlić-Mažuranić, prijevod na slovački jezik, književni prijevod, novo čitanje, svjetska književnost za djecu i mladež

\section{Priče iz davnine in slowakischer Sprache und im Kontext des Neuen Lesens}

Im Beitrag setzt man sich mit dem Konzept der Weltliteratur für Kinder und Jugendliche auseinander, die hier in einen beständigen, unveränderbaren Teil und einen veränderbaren Teil, der erst zu entdecken und anzuerkennen ist, aufgeteilt wird. Ivana Brlić-Mažuranićs Werk Priče iz davnine gehört zum beständigen Teil der Weltliteratur für Kinder und Jugendliche. Die Übersetzung dieser Märchensammlung ist nicht nur wegen der darin enthaltenen Wertvorstellungen, sondern auch aus pragmatischen Zwecken zum festen Bestandteil der slowakischen Kinder- und Jugendliteratur geworden. Im Beitrag wird der genrespezifische Aufbau der Sammlung besprochen, der aus dem Zusammenspiel von drei kinderliterarischen Genres besteht. Dabei werden zwei unterschiedliche slowakische Sammlungsübersetzungen analysiert: Rozprávky z pradávna (1976) und Ctiborova hora a iné rozprávky (1991), die von ein und demselben Übersetzer, Zlatko Klátik, stammen, wobei im letztangeführten Titel sprachliche Änderungen festzustellen sind. Besonderes Interesse wird dem Konzept des Neuen Lesens gewidmet, das auf Textunterschiede ausgerichtet ist. Neues Lesen ist als ein progressiver Prozess der Wiederbelebung älterer literarischer Werke und der Übernahme fremdliterarischer Texte seitens der zeitgenössischen jungen Leser zu verstehen, der die Lust am Lesen alter Geschichten steigern sollte.

Schlüsselwörter: Priče iz davnine, Ivana Brlić-Mažuranić, Übersetzung ins Slowakische, literarische Übersetzung, Neues Lesen, Weltliteratur für Kinder und Jugendliche 